is given, as well as attention to the need for the preparation and training of foster parents.

Attention is given to interpersonal relations in family-type orphanages, which is an indispensable condition for the child's entry into society, the formation of her family values, proper self-evaluation and the realization of her as a social and communicative person.

It is proved that the upbringing of children in foster families makes it possible to preserve the most important thing for them - family socialization in normal family conditions, which allows an orphan child not to feel «exiled» in the society.

Key words: orphanage, foster family, parental care, deprivation, adaptation, family-type orphanage, self-esteem, self-affirmation, family values, palliative care, palliative-rehabilitation center.

Стаття надійшла до редакції 28.08.2018

І. В. Поліщук

\title{
ПРОБЛЕМА НАЦІОНАЛЬНО-ПАТРІОТИЧНОГО ВИХОВАННЯ У ПЕДАГОГІЧНІЙ СПАДЩИНІ Т. Д. ДЕМ'ЯНЮК
}

Анотація. У статті розглядається педагогічна спадщина Тамари Дмитрівни Дем'янюк щодо реалізації національно-патріотичного виховання в Україні, зокрема проаналізовано основні наукові й методичні праці педагога, як-то: «Формування особистості засобами народознавства», «Орієнтовна регіональна програма національного виховання учнівської молоді», «Інноваційні технології громадянського виховання учнівської молоді», «Педагогічні основи демократизації та гуманізації виховного процесу в загальноосвітній школі», «Духовноморальний розвиток особистості учня в умовах діяльності української національної «Школи-родини»», «Організація виховного процесу в сучасному загальноосвітньому навчальному закладі», «Національний проект: На крилах історії чи у своїй мушлі». 3'ясовано, що ідеї національно-патріотичного виховання займали провідне місце у педагогічній спадщині Т. Д. Дем’янюк: учена розробила та реалізовувала на практиці положення i рекомендації щодо вдосконалення процесу національно-патріотичного виховання учнів, запроваджувала інноваційні форми i методи національно-патріотичного виховання у експериментальних закладах освіти.

Ключові слова: Т. Д. Дем'янюк, національно-патріотичне виховання, патріотизм, Батьківщина, педагогічна спадщина.

Постановка проблеми. Процес розбудови й утвердження суверенної, правової, демократичної, соціально орієнтованої держави, 
пов'язаний зі становленням в Україні громадянського суспільства, передбачає докорінне переосмислення національно-патріотичного виховання учнів молодшого шкільного віку як особливої категорії школярів. Саме в сучасному освітньо-виховному закладі мають бути створені всі умови для оволодіння особистістю школяра системою національних, загальнолюдських цінностей для формування патріотизму, відповідальності за долю нації, держави, розвитку психологічної готовності та практичної здатності виконувати громадянські обов'язки, передбачені Конституцією та законами України, у мирний та військовий час.

Аналіз останніх досліджень 3 проблеми. Теоретичні основи проблеми національно-патріотичного виховання розкрито у працях науковців: науково-теоретичні положення національно-патріотичного виховання (Г. Ващенко, Д. Донцов, К. Ушинський, С. Русова, А. Макаренко, М. Стельмахович, В. Сухомлинський,); теоретичні дослідження сутності національно-патріотичного виховання (О. Вишневський, В. Кузь, .. Руденко, Б. Ступарик); впровадження інноваційних форм роботи в позаурочній діяльності (О. Киричук, О. Петренко, Т. Дем'янюк, С. Максименко).

Мета пропонованої статті - проаналізувати педагогічну спадщину Т. Д. Дем'янюк стосовно національно-патріотичного виховання учнів.

Виклад основного матеріалу дослідження. Сучасне розуміння національно-патріотичного виховання зумовлене соціальним замовленням Української держави в галузі освіти й виховання, задеклароване в законах України «Про освіту» [17], «Про загальну середню освіту» [18] та конкретизується Державною національною програмою «Освіта» («Україна XXI століття») [16], Національній доктрині розвитку освіти України в XXI столітті [21], Концепції національного виховання [19], Концепції громадянського виховання особистості в умовах розвитку української державності [20] та ін. У зазначених нормативно-правових документах головною метою української системи освіти i виховання визначено створення умов для формування особистості професіонала-патріота країни, який усвідомлює свою належність до сучасної європейської цивілізації, чітко орієнтується в сучасних реаліях і перспективах розвитку держави, має патріотичні почуття, осмислення нерозривної єдності з патріотизмом попередніх поколінь, прагнення зайняти у житті і суспільстві провідне місце. Тому, проблема національно-патріотичного виховання розглядається на державно-програмному та концептуальному рівнях.

Відомий вчений, педагог Т. Д. Дем'янюк у багатьох наукових працях актуалізувала увагу на проблемах національно-патріотичного виховання школярів, зокрема: не повністю реалізується принцип народності, основна цінність якого сконцентрована у народознавстві, національній культурі, історії, мові; знижує ефективність роботи одноманітність форм, зайве копіювання шкільної виховної практики; 
відсутність інтересу до введення інновацій у процес національнопатріотичного виховання; школярі не залучаються до активно-творчої національно-патріотичної діяльності, особливо у позаурочний час; не враховуються їхні вікові, індивідуальні особливості; наявна безсистемність в організаційно-педагогічних діях, що призводить до відсутності цілісної системи національно-патріотичного виховання [8].

У науково-педагогічній спадщині Т. Д. Дем'янюк ми знаходимо фундаментальні положення щодо національно-патріотичного виховання дітей та учнівської молоді, акцентуючи: «Національно-патріотичне виховання - це вироблення в особистості учня потреби активно діяти для влаштування власного життя, розбудови держави, проявляти, оцінювати, аналізувати власні та людські вчинки, якості, суспільно-політичні явища 3 точки зору патріотизму i національних цінностей» [8]. Національнопатріотичне виховання розглядається ученою як «дієвий засіб формування такого типу особистості, якій притаманне почуття людської гідності, прагнення служити людям, миролюбство, потреба захисту рідних земель» [6]. Водночас національно-патріотичне виховання школярів є «...одним із дієвих чинників, мета, зміст, завдання, основні складові якого дають можливість формувати освіченого, переконаного, відданого народу активного конкурентоспроможного патріота, здатного жити і працювати в умовах демократії, в обстановці зростаючої економічної і суспільної відповідальності за себе і свою державу» [7, с.12].

Великий резонанс в освітянському середовищі мала і має сьогодні невелика за розміром, але конструктивна за змістом, книга Т. Д. Дем'янюк «Педагогічні основи демократизації та гуманізації виховного процесу в загальноосвітній школі» [1]. Це була одна 3 перших у галузі теорії і методики виховання спроба усвідомлення перших років новітньої української історії, становлення незалежності й перших реформаторських кроків у здійсненні виховного процесу. На багатому теоретикометодологічному матеріалі в книзі переосмислюється гуманне ставлення українського Вчителя до особистості учня, окреслюються новітні шляхи виховання національно свідомої, громадянсько-дієздатної особистості, спроможної відстояти свої патріотичні почуття, виражені в національних ідеях та ідеалах. Викладений матеріал $є$ й сьогодні актуальним для використання. Книга є одним з перших фундаментальних досліджень, де в узагальненому вигляді зроблено оцінку успіхів i сутностей, закономірностей і специфічних особливостей національно-патріотичного виховання підростаючого покоління на початку державотворчого процесу в Україні.

Тамара Дмитрівна вписала нові сторінки в методику використання народної педагогіки у процесі реалізації Концепції національного виховання [5], співавтором якої вона була. Актуальним на сьогодні залишається іiі посібник «Народознавство в школі: досвід, проблеми, пошуки» [4], в якому запропоновано новітню модель формування 
особистості учня-патріота засобами народознавства. Народна педагогіка стала для Тамари Дмитрівни першоосновою ії професійної та наукової діяльності, учена переконувала, що «...народна педагогіка - це зосередження духовного життя народу, бо в ній розкриваються особливості національного характеру українців; глибока повага та любов до родини, інших людей, дійова готовність надати допомогу, пошана до праці, трудова майстерність, дбайливе ставлення до природи, виявлення патріотичних почуттів» [3, с. 20].

Найпершим обов'язком вчителя початкових класів педагог вважала знання сутності патріотизму, вікових, психологічних, етнічних особливостей учнів, включення їх у навчально-пізнавальну, суспільногуманістичну, національно-патріотичну, активно-творчу діяльність.

Отже аргументований автором високий рівень патріотизму характеризується стійкою мотивацією в учнів, бажанням включатися в освітню та інші види діяльності патріотичного спрямування, творчим пізнанням себе і суспільства, держави загалом; високим усвідомленням своєї ідентичності з рідним народом та творчими вміннями, які дозволяють виявляти бажання і готовність до розбудови держави. Середній рівень характеризується вибірковою мотивацією, яка дає змогу достатньо пізнавати взаємозалежність своїх прав і обов'язків, визначальних атрибутів державності та характеризується продуктивним пізнанням світу і себе в ньому. Їхні уміння є продуктивними, оскільки беруть участь у всіх видах практичної діяльності і чітко усвідомлюють свою життєву позицію. Низький рівень вираження патріотизму школярів окреслюється ситуативною мотивацією до їх включення у запропоновані, а не творчі види діяльності; репродуктивним пізнанням законів, атрибутів державності; нечітким усвідомленням взаємозв'язку 3 культурою, звичаями і традиціями рідного народу, а також незначними уміннями, що проявляються в обмежених видах діяльності [4].

Розробляючи, наприклад, посібники з національно-патріотичного виховання, педагог-дослідник керувалася переконаннями, що «Батьківщина починається 3 сім’ї», що «найважливіші риси і якості громадянина-патріота зароджуються в родині», а «діти - продовження не тільки нашого роду, а й нашого соціального ладу, наших завоювань, досягнень, благородних намірів». Її навчально-методичні посібники виходять за рамки науково-педагогічних рекомендацій та порад. Ці книги громадянського спрямування, в яких Тамара Дмитрівна як громадянин, патріот, трибун, поборник найпередовіших ідей і поглядів доносить до читачів актуальні, своєчасні положення національно-патріотичного виховання дітей та учнівської молоді $[9,13,14]$.

Розкриваючи сутність теоретичних положень національнопатріотичного виховання, науковець розглядала його у взаємозв'язку 3 поняттям «громадянське», зміст і сутність якого сягає античних часів філософії і педагогіки. «Невід’ємною складовою виховання українських 
патріотів є громадянське виховання, бо реалії життя такі, що українське суспільство, вступивши понад два десятиліття тому на шлях демократії, ще нині перебуває у стані формування громадянського суспільства», стверджувала вона [8]. Цей процес і кінцевий результат передбачає не лише встановлення певних стосунків на рівні держави щодо суспільства, але й ставить вимоги до становлення самої людини, перед якою стоїть, як зазначала Тамара Дмитрівна, перш за все, психологічна готовність узяти на себе відповідальність за їі «завтрашній день». Саме звідси витікає їі теорія відповідальності особистості перед собою, за власне життя, тобто теорія самовідповідальності та самодостатності, що веде до розвитку в характері рис патріотизму, підприємливості, творчості, свідомості відповідального вибору траєкторій життя, готовності до захисту власних прав і свобод [15].

Під керівництвом педагога-практика Т. Дем'янюк досліджувалися важливі проблеми становлення системи національно-патріотичного виховання учнів молодшого шкільного віку, в поєднанні з громадянським, сімейно-родинним, трудовим вихованням та ін.; здійснювався науковий пошук шляхів реалізації Концепції національного виховання; розроблялися освітньо-виховні технології та програмно-методичне забезпечення підготовки педагогічних кадрів до здійснення виховного процесу в окремому експериментальному навчальному закладі; проводилася апробація та узагальнення результатів наукових досліджень в рамках діяльності Науково-дослідної лабораторії інноваційних виховних технологій, яку вона очолювала більше п'ятнадцяти років, а також кафедри теорії і методики виховання, якою вона успішно керувала більше двадцяти років.

Книги кандидата педагогічних наук, заслуженого працівника освіти України Т.Дем'янюк зацікавлюють педагогів-практиків, спонукають глибоко задуматися над проблемами, а основне - стають дороговказом, порадником для тих, хто має справу 3 національно-патріотичного вихованням дітей. Поєднання громадянського, духовного-морального, трудового, родинного виховання створює в наукових дослідженнях Тамари Дмитрівни особливу тональність, що вже сама по собі посилює педагогічне звучання теоретико-методологічних положень національнопатріотичного виховання: «Інноваційні технології громадянського виховання учнівської молоді» [8]; «Організація виховного процесу в сучасному загальноосвітньому закладі» [10,11]; «Духовно-моральне виховання особистості: інноваційний підхід» [2, 9, 13]; «Інноваційні технології трудового виховання учнів» [12] та ін.

Як член Комісії інноваційної діяльності та дослідноекспериментальної роботи в навчальних закладах України Науковометодичної ради 3 питань освіти МОН, молоді та спорту України Т. Дем'янюк була включена до складу робочих груп з розробки концепцій 3 питань національного виховання. Науковець була співавтором «Концепції національного виховання» (1994), «Концепції виховання 
студентів Рівненського державного гуманітарного університету» (2002), «Концепції виховання громадянина України» (2004), «Концепції формування позитивної мотивації на здоровий спосіб життя у дітей та молоді» (2004).

Висновки і перспективи подальших розвідок. Т. Д. Дем'янюк переконувала, що лише патріот, людина, яка дієво любить свою Батьківщину, свій народ, вболіває за його майбутнє, здатна бути конкурентноспоможним фахівцем. У своїй педагогічній діяльності педагог вдало використовувала традиції народної педагогіки, народну мудрість, що сторіччями формувалася через практичний національно-патріотичний досвід, передавалася з покоління в покоління.

Розроблені Т. Д. Дем'янюк положення, висновки, рекомендації щодо вдосконалення процесу національно-патріотичного виховання учнів, ï узагальнення у комплексній програмі національно-патріотичного виховання; запровадження інновацій у освітній процес, знайшли своє відображення у сучасній освітньо-виховній парадигмі; у вдосконаленні управління освітнім процесом закладів освіти на основі функціональноорганізаційного структурування цього процесу; активному залученні учнів до засвоєння історико-культурного досвіду українського народу.

Перспективи подальших наукових пошуків вбачаємо у більш детальному вивченні внеску Тамари Дмитрівни Дем'янюк у розробку системи національно-патріотичного, громадянського виховання учнів молодшого шкільного віку у контексті реалізації Концепції «Нова українська школа».

\section{СПИСОК ВИКОРИСТАНИХ ДЖЕРЕЛ:}

1. Бойко А. М. Оновлена парадигма виховання: шляхи реалізації (підготовка вчителя до формування виховуючих відносин 3 учнями): Навчально-методичний посібник. // А. М. Бойко. - К.: 13 МЦ1996. - 105 с.

2. Дем'янюк Т. Д. Виховання духовності учнів загальноосвітньої школи засобами народознавства / Т. Д. Дем'янюк // Матеріали наук.-прак. конф. - Рівне: ІПКПК, 1992. - С. 16-18.

3. Дем'янюк Т. Д. Формування особистості засобами народознавства: посібник для вчителів та студентів педінституту / Т. Д. Дем'янюк. Рівне: ОІУВ, 1992. - 48 с.

4. Дем'янюк Т. Д. Народознавство в школі: досвід, проблеми, пошук / М-во освіти і науки України, Інститут системних досліджень. К.:Інформ.-вид. Центр «Київ», 1993. - 80 с.

5. Дем'янюк Т. Д. Концепція національного виховання: [схвалена Всеукраїнською пед. радою працівників освіти 30 червня 1994p.] / Т. Дем'янюк, І. Бех, П. Щербань // Освіта. - 1994, 26 жовт. ; Поч. шк.- 1996.- № 2. - С. 42-52. 
6. Дем'янюк Т. Орієнтовна регіональна програма національного виховання учнівської молоді / Т. Дем'янюк, Н. Савчук, О. Приходько та ін. - Рівне: РДПІ, 1994. - 24 с.

7. Дем'янюк Т. Д. Експериментальні навчальні заклади Рівненщини: (Анот. Каталог): Інформ. Бюлетень. Вип. 1 / Т. Д. Дем’янюк, С. В. Кириленко, О. Б. Петренко та ін. ; М-ство освіти і науки України, Наук.-метод. центр середньої освіти, РДГУ, Упр. освіти і науки Рівн. обл. держадміністрації, Наук.-дослідна лаб. інноваційних виховних технологій. - Рівне, 2003. - 42 с.

8. Дем'янюк Т. Д. Інноваційні технології громадянського виховання учнівської молоді: Навч.-метод. посіб. / Т. Д. Дем'янюк, Т. Ф. Умурзакова, Л. В. Манюк, І. П. Яремчук; Наук.-метод. центр серед. освіти. - К., 2003. - 264 с.

9. Дем'янюк Т. Д. Духовно-моральний розвиток особистості учня в умовах діяльності української національної «Школи-родини» / Т. Д. Дем’янюк // Науковий вісник. - 2005. - № 1. - С. 77-83.

10. Дем'янюк Т. Д. Організація виховного процесу в сучасному загальноосвітньому навчальному закладі: наук.-метод. посіб. / Т. Д. Дем'янюк; М-ство освіти і науки України, Наук.-метод. центр середньої освіти. - К., 2006. - 416 с. - Бібліогр.: с. 406-412.

11. Дем'янюк Т. Д. Організація виховного процесу в сучасному загальноосвітньому навчальному закладі: наук.-метод. посіб. / Т. Д. Дем'янюк; М-во освіти і науки України, Ін-т інновац. технологій і змісту освіти. - Суми: Антей, 2006. - 384 с. - Бібліогр.: c. $374-378$.

12. Дем'янюк Т. Д. Інноваційні технології трудового виховання учнів: наук.-метод. посіб. / Т. Д. Дем'янюк, Г. Ф. Вознюк, Г. В. Сухолейстер; М-во освіти і науки України, Ін-т інновац. Технологій та змісту освіти, РДГУ [та ін.]. - К.-Рівне: Волинські обереги, 2008. - 175 с. - Бібліогр.: с. 143.

13. Дем'янюк Т. Д. Духовно-моральне виховання учнів в умовах школи-родини: наук.-метод. посіб. / Т. Д. Дем'янюк, Є. І. Камінська; Науково-методична рада МОН. - Рівне: Волинські обереги, 2009. - 323 с.

14. Дем'янюк Т. Д. Національний проект: На крилах історії чи у своїй мушлі: Навчально-методичний посібник/ Т. Д. Дем'янюк, О. Р. Іщук, О. В. Поцекайло. - Рівне: РДГУ, 2010. - 153 с.

15. Дем'янюк Т. Д. Формування духовно-моральних якостей особистості гімназиста в умовах розбудови громадянського суспільства: Науковий вісник/ Т. Д. Дем'янюк, В. Г. Ординська. Рівне: РДГУ, 2010. - 121с.

16. Державна національна програма «Освіта» (Україна XXI століття) К.: Радуга, 1994. - 61 с.

17. Закон України «Про освіту» - К.: Генеза, 1996. - 36 с. 
18. Закон України «Про загальну середню освіту» // Інформаційний збірник МОН України. - 1999. - № 15 (серпень). - С. 6-31.

19. Концепція національного виховання // Рідна школа. - 1995. - №6. C.13 - 14 .

20. Концепція громадянського виховання особистості в умовах розвитку української державності // Освіта України. - 2000. - №35 (серпень). - С.13-14.

21. Національна доктрина розвитку освіти України у XXI столітті // Освіта України. - 2001. - № 22. - С. 2 - 6.

22. Сухомлинський В. О. Вибр. твори: В 5-ти томах / В. О. Сухомлинський. - К.: Рад. школа, 1997. - Т. 5. - 200 с.

\section{REFERENCES TRANSLATED AND TRANSLITERATED:}

1. Boiko A. M. Onovlena paradyhma vykhovannia: shliakhy realizatsii (pidhotovka vchytelia do formuvannia vykhovuiuchykh vidnosyn $\mathrm{Z}$ uchniamy) [Updated Paradigm of Education: Ways of Realization (preparing a teacher to formation a training relationship with students ] : Navchalno-metodychnyi posibnyk. // A. M. Boiko. - K.: 13 MTs1996. 105 s. (in Ukrainian)

2. Demianiuk T. D. Vykhovannia dukhovnosti uchniv zahalnoosvitnoi shkoly zasobamy narodoznavstva [Education of the Spirituality of Pupils of a Secondary School by Means of Ethnography ] / T. D. Demianiuk // Materialy nauk.-prak. konf. - Rivne: IPKPK, 1992. - S. 16-18. (in Ukrainian)

3. Demianiuk T. D. Formuvannia osobystosti zasobamy narodoznavstva: posibnyk dlia vchyteliv ta studentiv pedinstytutu [Formation of Personality by Means of Ethnography: a manual for teachers and students of the pedagogical institute] / T. D. Demianiuk. - Rivne: OIUV, 1992. - 48 s. (in Ukrainian)

4. Demianiuk T. D. Narodoznavstvo v shkoli: dosvid, problemy, poshuk [Ethnology at Ichool: Experience, Problems, Search] / M-vo osvity i nauky Ukrainy, Instytut systemnykh doslidzhen. - K.:Inform.-vyd. Tsentr "Kyiv", 1993. - 80 s. 9in Ukrainian)

5. Demianiuk T. D. Kontseptsiia natsionalnoho vykhovannia: [skhvalena Vseukrainskoiu ped. Radoiu pratsivnykiv osvity 30 chervnia 1994r.] [The Concept of National Education: [approved by the All-Ukrainian Ped. Board of Education June 30, 1994] / T. Demianiuk, I. Bekh, P. Shcherban // Osvita. - 1994, 26 zhovt. ; Poch. shk.- 1996.- No 2. - S. 42-52. (in Ukrainian)

6. Demianiuk T. Oriientovna rehionalna prohrama natsionalnoho vykhovannia uchnivskoi molodi [The Indicative Regional Program of National Education for Students] / T. Demianiuk, N. Savchuk, O. Prykhodko ta in. - Rivne: RDPI, 1994. - 24 s. (in Ukrainain)

7. Demianiuk T. D. Eksperymentalni navchalni zaklady Rivnenshchyny 
[Experimental Educational Institutions of the Rivne Region]: (Anot. Kataloh): Inform. Biuleten. Vyp. 1 / T. D. Demianiuk, S. V. Kyrylenko, O. B. Petrenko ta in. ; M-stvo osvity i nauky Ukrainy, Nauk.-metod. tsentr serednoi osvity, RDHU, Upr. osvity i nauky Rivn. obl. derzhadministratsii, Nauk.-doslidna lab. innovatsiinykh vykhovnykh tekhnolohii. - Rivne, 2003. - 42 s. (in Ukrainian)

8. Demianiuk T. D. Innovatsiini tekhnolohii hromadianskoho vykhovannia uchnivskoi molodi [Innovative Technologies of Civic Education of Pupils]: Navch.-metod. posib. / T. D. Demianiuk, T. F. Umurzakova, L. V. Maniuk, I. P. Yaremchuk; Nauk.-metod. tsentr sered. osvity. - K., 2003. - 264 c. (in Ukrainian)

9. Demianiuk T. D. Dukhovno-moralnyi rozvytok osobystosti uchnia v umovakh diialnosti ukrainskoi natsionalnoi "Shkoly-rodyny" [Spiritual and Moral Development of the Student's Personality in the Conditions of Activity of the Ukrainian National "School-family"] / T. D. Demianiuk // Naukovyi visnyk. - 2005. - No 1. - S. 77-83. (in Ukrainian)

10. Demianiuk T. D. Orhanizatsiia vykhovnoho protsesu v suchasnomu zahalnoosvitnomu navchalnomu zakladi [Organization of Educational Process in a Modern General Educational Institution: textbook]: nauk.metod. posib. / T. D. Demianiuk; M-stvo osvity i nauky Ukrainy, Nauk.metod. tsentr serednoi osvity. - K., 2006. - 416 s. - Bibliohr.: s. 406412. (in Ukrainian)

11. Demianiuk T. D. Orhanizatsiia vykhovnoho protsesu v suchasnomu zahalnoosvitnomu navchalnomu zakladi [Organization of Educational Process in a Modern General Educational Institution: textbook]: nauk.metod. posib. / T. D. Demianiuk; M-vo osvity i nauky Ukrainy, In-t innovats. tekhnolohii i zmistu osvity. - Sumy: Antei, 2006. - 384 s. Bibliohr.: s. 374-378. (in Ukrainian)

12. Demianiuk T. D. Innovatsiini tekhnolohii trudovoho vykhovannia uchniv [Innovative Technologies of Labor Education of Students: textbook]: nauk.-metod. posib. / T. D. Demianiuk, H. F. Vozniuk, H. V. Sukholeister; M-vo osvity i nauky Ukrainy, In-t innovats. Tekhnolohii ta zmistu osvity, RDHU [ta in.]. - K.-Rivne: Volynski oberehy, 2008. - 175 s. - Bibliohr.: s. 143.

13. Demianiuk T. D. Dukhovno-moralne vykhovannia uchniv v umovakh shkoly-rodyny [Spiritual and Moral Upbringing of Pupils in the Conditions of the School-family] : nauk.-metod. posib. / T. D. Demianiuk, Ye. I. Kaminska; Naukovo-metodychna rada MON. Rivne: Volynski oberehy, 2009. - 323 s.(in Ukrainian)

14. Demianiuk T. D. Natsionalnyi proekt: Na krylakh istorii chy u svoii mushli [National Project: On the wings of history or in its Shell: textbook]: Navchalno-metodychnyi posibnyk/ T. D. Demianiuk, O. R. Ishchuk, O. V. Potsekailo. - Rivne: RDHU, 2010. - 153 s. (in Ukrainian) 
15. Demianiuk T. D. Formuvannia dukhovno-moralnykh yakostei osobystosti himnazysta v umovakh rozbudovy hromadianskoho suspilstva: Naukovyi visnyk [Formation of Spiritual and Moral Qualities of a Student's Personality in the Conditions of Civil Society Development] / T. D. Demianiuk, V. H. Ordynska. - Rivne: RDHU, 2010. - 121s.

16. Derzhavna natsionalna prohrama "Osvita" (Ukraina XXI stolittia) [The State National Program "Education" (Ukraine XXI century] - K.: Raduha, 1994. - 61 s. (in Ukrainian)

17. Zakon Ukrainy "Pro osvitu" [The Law of Ukraine "On Education]]- K.: Heneza, 1996. - $36 \mathrm{~s}$.

18. Zakon Ukrainy "Pro zahalnu seredniu osvitu" [The Law of Ukraine "On the general Secondary Education] // Informatsiinyi zbirnyk MON Ukrainy. - 1999. - No 15 (serpen). - S. 6-31.

19. Kontseptsiia natsionalnoho vykhovannia [Concept of the National Education]// Ridna shkola. - 1995. - No 6. - S.13-14. (in Ukrainian)

20. Kontseptsiia hromadianskoho vykhovannia osobystosti v umovakh rozvytku ukrainskoi derzhavnosti [Concept of Civic Education of the Person in the Conditions of Development of Ukrainian Statehood] // Osvita Ukrainy. - 2000. - No 35 (serpen). - S.13-14.

21. Natsionalna doktryna rozvytku osvity Ukrainy u XXI stolitti [The National Doctrine of the Development of Ukrainian Education in the 21st Century] // Osvita Ukrainy. - 2001. - № 22. - S. 2-6. (in Ukrainian)

22. Sukhomlynskyi V. O. Vybr. tvory: V 5-ty tomakh [Selected works. In 5 vol.]/ V. O. Sukhomlynskyi. - K.: Rad. shkola, 1997. - T. 5. - 200 s. (in Ukrainian)

Аннотация. В статье анализируется педагогическое наследие Тамары Дмитриевны Демьянюк относительно реализации национальнопатриотического воспитания в Украине, в частности проанализированы основные научные и методические работы педагога, а именно: «Формирование личности средствами народоведения», «Ориентировочная региональная программа национального воспитания учащейся молодежи», «Инновационные технологии гражданского воспитания учащейся молодежи», «Педагогические основы демократизации и гуманизации воспитательного процесса в общеобразовательной школе», «Духовноморальное развитие личности ученика в условиях деятельности украинской национальной «Школы-Семьи»», «Организация воспитательного процесса в современном общеобразовательном учебном заведении», «Национальный проект: На крыльях истории или в своей ракушке». Выяснено, что идеи национально-патриотического воспитания занимали значительное место в педагогическом наследии Т. Д. Демьянюк: ученая разработала, реализовала на практике положения, рекомендации относительно усовершенствования процесса национально- 
патриотического воспитания учеников, апробировала инновационные формы и методы национально-патриотического воспитания в экспериментальных учебных заведениях.

Ключевые слова: Т. Д. Демьянюк, национально-патриотическое воспитание, патриотизм, Родина, педагогическое наследие.

Abstract. The article deals with the pedagogical heritage of Tamara Dmytrivna Demianiuk concerning the implementation of national-patriotic education in Ukraine, in particular, the main scientific and methodological works of the teacher are analyzed, such as: "Formation of the personality by means of ethnology", "Indicative regional program of national education for students", "Innovative technologies of civic education for students", "Pedagogical foundations of democratization and humanization of the educational process in a secondary school", "Spiritual and moral development of the student's personality in the conditions of activity of the Ukrainian national "School-family", "Organization of educational process in a modern general educational institution", "National project: On the wings of history or in its shell"'.

It was found out that the ideas of national patriotic education took the leading place in the pedagogical heritage of $T$. Demianiuk: the scientist developed, implemented in practice the principles, recommendations for the improvement of the process of national-patriotic education of students, introduced innovative forms and methods of national-patriotic education in experimental educational institutions.

Key words: T. D. Demianiuk, national patriotic education, patriotism, Motherland, pedagogical heritage.

Стаття надійшла до редакції 25.09.2018

Н. І. Станіславчук

\section{РОЛЬ ЕТИЧНОЇ КОМПЕТЕНТНОСТІ ПРИ ПІДГОТОВЦІ МАЙБУТНІХ ВЧИТЕЛІВ ІНОЗЕМНОЇ МОВИ}

Анотація. У статті розглядається роль етичної компетентності при підготовці майбутніх вчителів іноземної мови. Узагальнено та систематизовано наукові погляди діячів освіти щодо поняття «компетентність» та «етична компетентність» зокрема. Проведено теоретичний аналіз, виокремлено основні аспекти досліджуваного поняття. Етична компетентність майбутнього учителя розглядається як складова його професійної компетентності. Досліджуючи теоретичну складову проблеми проаналізовано питання важливості володіння етичною компетентністю в умовах гуманізації освітнього процесу.

Ключеві слова: компетентність, етична компетентність, етичні 